\title{
THE INTELLIGIBLE GODS IN THE PLATONIC THEOLOGY OF PROCLUS
}

\author{
EDWARD P. BUTLER
}

The Platonic Theology is the culminating work of Proclus' long career and one of the defining works of late antiquity, but it has had few modern philosophical admirers. The exception, and an important one, is Hegel, who clearly drew inspiration from the Platonic Theology for his Science of Logic, and who draws his admiring account of Proclus in his Lectures on the History of Philosophy largely from his reading of this work. Nevertheless, the Platonic Theology has received far less attention from philosophers than it might have. A key reason for this neglect, I suggest, has been the inability to perceive in the procession of the divine orders as presented in the Platonic Theology a unifying logic akin to that in the Science of Logic. Such is the judgment of Hegel himself, who, despite his overall high praise of Proclus in the Lectures, characterizes the dialectic of the Platonic Theology as "external".

If the procession recounted in the Platonic Theology is, fundamentally, simply the multiplication of an hypostatized One, then Hegel would be correct, and Proclus' system lacks an inner logic. Moreover, on such an interpretation, causality in Proclus' system as a whole would be mystified, which would contribute to the perception of this grand edifice of Neoplatonic thought as little more than a highly developed form of irrationalism. The present essay, however, offers an interpretation of Proclus' system in which the procession of Being begins not from an hypostatized One, but in the manifold of individual, supra-essential henads, treating this procession not as a simple passage from unity to multiplicity, but as a transition from one mode of unity to another. In a previous essay, ${ }^{1} \mathrm{I}$ have discussed the difference between the modes of unity of the henads and of beings; the present essay argues that the Platonic Theology exhibits the emergence of the latter mode of unity from the former.

The beginning of the procession of Being cannot be from "the One", because there is, in a most important sense, no such thing: the first principle is not, in itself, a cause. The beginning, rather, is from the henads. This is why the Platonic Theology is a theology. The Gods constitute Being, and do so simply by virtue of being-Gods. The Platonic Theology is not therefore about the creation of the Gods, but about their nature, and how this nature determines the nature of Being. The aspect of the Gods from which the procession of Being begins, and which drives it throughout its several stages, I argue, is their individuality. That is, the meaning I propose for the statement that the procession of Being begins

\footnotetext{
1 "Polytheism and Individuality in the Henadic Manifold," Dionysius 23 (2005), 83-104.
} 
from the One is that Being proceeds from individuality as such. ${ }^{2}$ The procession of the divine orders as presented in the Platonic Theology will lack a unifying logic so long as the procession of the divine orders from the One is seen as the genesis of the Gods from the One. Rather, the Platonic Theology is an account of the emergence of Being from the Gods, which is a passage from existence to essence, huparxis to hupostasis. Being emerges from an existing divine manifold through the objectification of the existential individuality primordially possessed by each God qua God, with each successive plane of Being reflecting a stage in the ordering, or diakosmêsis, of this divine manifold. This process begins in earnest in the Platonic Theology's third book, which concerns the intelligible Gods.

Being has a wide and a narrow sense in Proclus. In the wide sense, it refers to everything that is, excluding only the two kinds of nonbeing: privations, which fall short of existence, and the Gods, from whose superabundant existence Being radiates. In the narrow sense, Being refers to that in relation to which all other beings as beings orient themselves, the intelligible as such, and is distinguished therefore from Intellect, which thinks that which is, and from Life, the intellective medium connecting intellect and the intelligible. Being in this narrow sense has the structure of three triads, of which the first triad represents primary Being, Being qua Being as it were, while the second and third triads are Life and Intellect as implicit within Being, that is, Life and Intellect as modes of Being. In this way the structure of Being in the wide sense is explained by the structure of Being in the narrow sense. But what explains the differentiation of Being into just such modes of Being ? $^{3}$ For this, we must look to the first intelligible triad, which contains the nuclear structure of Being, so to speak.

The first intelligible triad is Limit, the Unlimited, and Mixture, the terms of the intellectual method Plato presents in the Philebus. Being is therefore in the most fundamental sense-which is at the same time the most universal sense because all the modes of Being unfold according to it-Limit, the Unlimited, and Mixture. But we can state it more narrowly, for Proclus explains that Being per $s e$ is the third moment, Mixture. And he is unequivocal that this means that Being is a product. For while the God "exhibits" [deixai] or "reveals" [ekphainein] Limit and the Unlimited, the God "makes" [poiein] the mixture through these two archai (PT III 9. 36.12-19). The significance of giving Being the status of a product is not lost on Damascius, who criticizes Proclus in this regard (DP III 109ff/R. I, 285); it is, indeed, one of the most profound differences between the two Platonic successors. For his own part, however, Proclus approaches the

\footnotetext{
2 On the One as principle of individuation in Plotinus, see recently A. Labecki, "The One and the Many: Part II: The Many," Dionysius 25 (2007), pp. 129-152.

3 Note that Damascius, in his commentary on the Parmenides, characterizes the explanation of the triplicity of the intelligible (to noêton) by virtue of the triplicity of substance (ousia) as a "more theological" (theologikôteros) mode of explanation (In Parm. 17. 4-6/R. II, 14).
} 
problem from a somewhat different perspective. The question Proclus asks is how this Mixture, although it is the very being of Being Itself, can nevertheless be a mixture composed of nonbeings, that is, of supra-essentials: "For if Limit and the Unlimited are supra-essential [huperousia], essence may appear to have its subsistence from non-essences. How therefore can non-essences produce essence?" (PT III 9. 38.13-16). To understand how Proclus answers this question, we need to go deeper into what Limit and the Unlimited are for him, and in particular their relationship to the henads or Gods.

Limit, Proclus explains, "is a God proceeding to the intelligible summit from the unparticipated and first God," while "the Unlimited is the inexhaustible power of this God," (i.e., the God who proceeds) and the Mixed is "the first and highest order [diakosmos] of the Gods," (PT III 12. 44.24-45.7). Limit is a God, the Unlimited is the power of the God, and the Mixed is an order of the Gods, the highest such. ${ }^{4}$ The Mixed is the highest order of the Gods because it is the most general classification of the Gods, just as the Mixed is the most general classification of beings. What is crucial here is the progression from a God, to a property of that God, to a class of Gods based upon the expression, or activity, of such properties (that is, 'powers'). The sense of this progression is therefore not multiplication, but classification, and it is this which is at the heart of the transition from that which is beyond Being, to Being Itself.

What exactly does Proclus mean when he states that Limit is $a$ God, and why ought the third moment of the triad be regarded as the result, not of multiplication, but rather of the classification of an existing individual? With respect to the question of multiplication, Proclus explicitly states that "a multiplicity of henads is discernible first in the first rank of the intelligible-and-intellectual," (IP 1091), that is, at the stage corresponding to the hypostasis of Life. The intelligible order of Gods, therefore, cannot constitute a multiplicity. Rather, the three intelligible triads correspond to three dispositions of henads considered strictly as individuals. Hence Proclus states that "the first triad is an intelligible God in the first place [prôtôs], that which comes after it an intelligible-and-intellectual God, and the third an intellectual God," (PT III 14. 51. 9-11). Proclus is not speaking of three particular Gods here, because he is not so perverse as to claim that one and one and one do not make three; and this is also why Limit is not a particular God named, as it were, Peras, but $a$ God as such, any God.

\footnotetext{
${ }^{4}$ On the relationship between the henads and the One ("the unparticipated and first God"), see my article in Dionysius 23 (2005). On the "unparticipated" specifically, see E; Butler (Ph.D. diss., New School for Social Research, 2003) "The Metaphysics of Polytheism in Proclus", esp. 157-172. Briefly, note ET prop. 23: "all participated substances [hupostaseis] are linked by upward tension [anateinontai] to existences [huparxeis] not participated"-that is, the opposition between the participated and the unparticipated is founded upon that between hupostasis and huparxis, on which more below. The opposition, I argue, is internal to the henads, and expresses the tension between their illumination of Being and their reservation of their own transcendence, rather than between the henads and an hypostatized One Itself.
} 
What Proclus means, I submit, is that the first triad is any God of the intelligible class, the second triad is any God of the intelligible-intellectual class, and the third triad is any God of the intellectual class. The triads, then, would represent the disposition of the Gods of these classes as individuals, prior to the account of the nature of the classes as assemblages, which is inseparable from the account of the activities of the Gods in these classes, these activities being the ontic structures of the relevant planes of Being. The use of protôs in the above quote should thus be compared to the statement at $P T$ III 21. 74. 7-8 that "just as the intelligible Gods are henads in the first place [prôtôs], so too are they fathers in the first place [prôtôs]." This passage refers to Proclus' technical use of the term "father" to characterize a mode of divine activity (a usage probably influenced by the Chaldaean Oracles): "All that is paternal in the Gods is of primal operation [prôtourgon] and stands in the position of the Good [en tagathou taxei] at the head of all the divine orders [diakosmêseis]," (ET prop. 151). The equivocation which can make the henadology confusing at times arises because the procession of Being takes place within the individual God him/herself, whose activity, characterizable as prôtôs, deuterôs and so forth, is the very site for the emergence of Being's stratified and hierarchical structure.

Whereas the organizations of the intelligible-intellectual and intellectual classes of Gods are treated in the fourth and fifth books of the Platonic Theology respectively, the intelligible class of Gods is treated in the third book itself. But if the second intelligible triad is "an intelligible-and-intellectual God," and the third intelligible triad is "an intellectual God," then the individual Gods of the intelligible-intellectual and intellectual classes are, when taken individually, intelligible Gods. That is, the first intelligible triad represents any God, taken in the widest universality, while the second and third triads already represent particular divine dispositions; indeed, what would make the most sense would be for the second to be more particular than the first and the third more particular than the second. This is the most sensible meaning to accord to the statement by Proclus that a multiplicity of henads is first discernible in the intelligible-andintellectual order: the latter is the first such particular disposition of the divine manifold.

Proclus remarks in the first book of the Platonic Theology that "such things as express characteristics of particular orders [idia tinôn diakosmôn] do not necessarily pertain to all the Gods, but those that pertain to all of the Gods a fortiori apply to each," (PT I 10. 43. 19-21). The intelligible order expresses the characteristics which apply most universally to the Gods, and therefore all the Gods qua Gods are intelligible Gods. This conclusion receives additional confirmation from the correspondence Proclus establishes between attributes common to the Gods in general (PT I 2. 9. 9-12)-most notably the perfections of goodness, wis- 
dom, and beauty (chap. 22-24) - $^{5}$ and the three intelligible triads (see esp. PT I 24. 108. 20-109. 2). The statement that those characteristics that pertain to all of the Gods apply a fortiori to each expresses an important corollary of the henadology's core doctrine, namely that all of the Gods are present in each (IP 1048). Expressing this doctrine with respect to the universal characteristics of the Gods reveals the principle according to which the polycentric manifold of the Gods comes to constitute the monocentric and hierarchical manifold of Being. ${ }^{6}$ To Being belongs the universality embodied in the divine characteristics. The transition from the supra-essential domain of the Gods to the ontic domain of essence is a transition, as it were, from the each of henadic uniqueness to the all of universality and ideality, this transition occurring within the first intelligible triad.

While the Platonic terminology for the first intelligible triad is the Limit, Unlimited, and Mixed of the Philebus, the expressions Proclus finds most systematically fruitful for this triad are "Existence" (huparxis), "Power" (dunamis), and "Intellect" (nous). Being qua Being is thus implicitly intellectual; and this explains why Proclus sometimes calls beings intellective and reserves for the Gods that intelligibility which, beyond that which is "the complement of intellection [plêrôtikon tês noêseôs]," is "defined according to the existence [huparxin] and unity [henôsin] of the divinity itself." It is in this sense that "the existence of the Gods," although beyond being, "is called intelligible" (PT I 26. 117.23-118.9). The "existence" or huparxis of the Gods is inherently individualized; thus Proclus speaks of the "existences", huparxeis, of the Gods when referring to their individual natures. In this sense, existence and individuality truly precede essence for Proclus.

Mediating between Existence and Being in the Gods, however, and therefore playing the truly crucial role in the emergence of Being from the Gods, is Power. "In all the divine genera," Proclus explains, "powers precede processions and generations," (PT III 24. 84.18-20). Proclus will frequently refer not to "power" in the singular, but to "powers", in the plural. This is important inasmuch as the progression from unity to multiplicity in the Platonic Theology is not a multiplication of the number of existing entities but in fact the coming to determinacy (diakrisis) of the multiplicity of powers within each deity. Through their powers becoming determinate the Gods, in effect, dirempt themselves, generating an ontic double which is formal rather than existential, a process which is the very emergence of Being. I will have more to say about this "doubling" of each henad below, but first we must understand the sense of powers as properties of the

\footnotetext{
5 "Socrates affirms that all that which is divine is beautiful, wise and good, and shows that this triad applies to all the processions of the Gods," (PT I 22. 101.1-3).

${ }^{6}$ On the polycentric nature of the henadic manifold, see my article in Dionysius 23 (2005). The polycentric nature of procession from the One is recognized by Jean Trouillard in La mystagogie de Proclos, Paris 1982, chap. 6, "Procession polycentrique," although without acknowledging that it is proper to the henads alone; Christian Guérard, "La théorie des hénades et la mystique de Proclus," Dionysius 6 (1982), has a more balanced account.
} 
Gods, because in the tension between the individual integrity of each God and the multiplicity of his/her properties or powers, the procession of Being finds its inner logic.

Proclus speaks about the "powers" of the Gods with a technical connotation which contrasts them with the Gods' "existences". In his commentary on the Parmenides, for instance, Proclus speaks of "shapes ... knowable and expressible as pertaining to the powers of the Gods, not to their huparxeis." It is in virtue of the latter, their "existences", Proclus says, that they possess "the characteristic of being Gods," although it is through the "shapes" pertaining to their powers that the Gods "become manifest to the intellectual eyes of souls," (IP 1128). The contrast between huparxis and power in the nature of the Gods can also be expressed in terms of henosis, the unity or integrity of the divine individual, as in $E T$ prop. 93, concerning the infinitude of superior principles relative to inferior ones: "though they [the inferiors] unfold the powers contained in it [the superior], yet it has something unattainable in its unity [henôsin]." We can see this general principle given specific theological application in some remarks from his Cratylus commentary on "the multitude of the powers of Apollo" (IC 174), which are, in their totality, "not to be comprehended, nor described by us. For how will human reason ever be able to comprehend all the $<$ individual $>$ properties (idiotêtôn) od Apollo, or any other God?" Here the existential uniqueness of Apollo is expressed by our incapacity to grasp exhaustively the totality of his powers, of which Proclus offers here the examples of "medicinal", "prophetic", and "harmonic", as well as the activity of archery.

"Powers", when taken in this fashion as properties of unique individuals, yield kinds, and therefore they both express the uniqueness of an individual and also embody the negation of that very uniqueness; hence their mediating role in the first intelligible triad. Thus in the Parmenides commentary, Proclus holds the existential dimension apart, explaining that "positive propositions apply to the monads of kinds of being, for the power of generating things is in these. The first principle is before every power and before assertions," (IP 74K). The contrast between an existential individuality and a multiplicity of powers, which is really the contrast between existential and ontic modes of unity, applies to the human individual as well, for Proclus states that "if indeed the divine is cognizable in any respect, it must be apprehended by the huparxis of the soul ... so that the most unical [henikotaton] must be known by the One and the ineffable by that which is ineffable," but to do this the soul must "lay aside the multiplicity of diverse and omniform powers in it," (PT I 3. 15.15-26). This does not mean that the individual is no longer an individual, however, as we can see from a discussion of prayer in the Timaeus commentary, which explains that prayer consists in focusing the attention such that, "becoming alone, we may associate with solitary deity, and not endeavor to conjoin ourselves with multitude to the One. For he who attempts this effects the very opposite, and separates himself from the 
Gods," (IT I, 212). Here the integrity of the individual worshiper approximates them to the supra-essential individuality of their deity.

Power, Proclus explains, is the relation (schesis) between the One and Being, a relation which has a double aspect (duoeides), "for it is of the One but adherent to Being [tô onti sumphuetai]; it is the motion of the One and <its> procession into Being," (PT III 24. 85.7-9). "Power," he says, "is supra-essential, but conjoined with [sumpheromenê] essence ... The powers of the Gods are supraessential and subsist together with [sunuparchousai] the very henads of the Gods. And through these <powers> the Gods are generative of beings," (PT III 24. 86.5-9). This generativity comes about by the "mingling" of henads into a unified essence: "Supra-essential natures do not themselves enter into the composition of the Mixed, but those remaining transcendent, secondary processions from them coalesce [sumphuomenôn] into the hypostasis of essence," (PT III 9. 38.24-27). This is how nonbeings constitute Being. But this means that Limit and the Unlimited "are each twofold, one prior to Being but the other in Being, and the one is generative but the other is an element of the mixture ... The Limit and Unlimited which are separate $<$ from Being $>$ subsist causally prior to the Mixture. But the Limit and Unlimited which are mixed are more imperfect than the Mixture," (PT III 10. 42.16-26). Limit and the Unlimited, insofar as they are supra-essential and do not become elements of the mixture, remain inseparable moments of the Gods' integral individuality, whereas Limit and the Unlimited as elements of an ontic mixture are dependent moments of the mixture, that is, of Being.

The powers of the Gods, therefore, can also be thought of as powers of Being. Existentially, that is, according to their huparxeis, each God is perfectly simple, their individuality unassailable by any means of analysis: "Only the Gods possess existence defined by singular simplicity, transcending all multiplicity insofar as they are Gods, superior to all division, fragmentation, alienation from or relation to secondary entities and all composition," (PT I 20. 95.18-22). Existentially, then, each God is utterly unique, since their attributes cannot be considered separately from their integral persons. If these attributes or powers are considered in themselves, however, they constitute a different sort of unity than that which is embodied in each God. It is for this reason that Proclus refers to the second intelligible triad, which unfolds the second moment of the first intelligible triad, as the first whole: "For there <in the first triad> everything is prior to parts and to wholeness, while in this $<$ second triad $>$ there are parts and whole, power having revealed itself," ( $P T$ III 25.5-7).

Each God contains all of Being; thus at IT I, 308. 3-6 Proclus says that "each of the Gods is the universe [to pan], but in a different way ... according to a divine peculiarity [idioteta]," and again at I, 312. 21-22 that "each of the Gods is named from his peculiarity [apo tês idiotêtos], though each is comprehensive [periektikon] of all things." Idiotês is designated by Proclus at IP 1049 as a technical term for henadic individuality, that which is expressed among beings by 
difference, heterotes, an intellectually mediated relation. Being is said in a wider and a narrower sense, as I remarked above, and Being in the narrow sense, Being Itself, is the ground of Being in the wider sense and is explicated in it. The richness of content which provides for this explication is the presence to Being and for Being of the manifold of the Gods, which is present in the first place and in its greatest intensity not as a manifold, but as each God's one-to-one relation to all of Being. The ground of Being is therefore that which is in immediate contact, not with a class of Gods, like the subordinate hypostases which are not Beingqua-Being, but with each God, as a unique individual existence (huparxis). In this fashion the polycentric manifold of the Gods is present to Being and grounds it to its furthest reaches.

The intelligible order of Gods, it was explained above, does not constitute a multiplicity in the ontological sense: "the intelligible genus of the Gods is unitarily exempt [exêrêtai ... heniaiôs] from all the other divine orders [diakosmôn] ... it transcends [ekbebêke] both universal and particular intelligibles and preexists all intellectual objects, being an unparticipated and divine intelligible," (PT III 28. 100.4-11). The intelligible genus of the Gods is not itself an intelligible universal because the henads do not participate anything. The Gods, Proclus states, "have no attribute by participation, but all according to existence [huparxis] or implicit in their causality [kat'aitian]," (ET prop. 118); and elsewhere, "every God is essentialized [ousiôtai] in being a God, or rather is supra-essentialized [huperousiotai], but there is nothing which is participated by him; because the Gods are the most ancient and venerable of all things," (IT I, 364). In his clearest programmatic statement with respect to the organization of manifolds in general, Proclus explains in the Elements of Theology that "for each class [taxis] there is a single monad prior to the manifold, which determines for the members [lit. coordinates, tetagmenoi] their common relation [hena logon] to one another and to the whole," (ET prop. 21, 11. 15-18). And so too for the henads; but because their monad is none other than the One Itself, which neither is, nor is one, the henads are not mediated by the One, but are rather immediately all in each.

Unlike individuals depending upon forms to individuate them, therefore, the henads possess "individuality much more perfect than the otherness of forms," (IP 1048). Each God is thus, qua God, one of a kind, and the manifold of the henads has a unique structure unlike any other manifold. Hence Proclus refers to "the totality of the divine set [pas ... theios arithmos], in virtue of which is the being, or rather pre-being [proeinai], of the Gods," (IP 1212). Thus unlike a manifold of beings, which would be disposed around a single center, the manifold of the henads is polycentric, deriving its collective character simply from the unique individuals who are its members. The very same characteristic, therefore, which makes the henads most individual is also that which makes the totality of them most united, namely the absence of a substantial mediator. It is, indeed, the emergence among the Gods of the basic structures governing the organization of multiplicities that is the condition of the possibility of such structures operating 
among beings. Hence Proclus states that Being "receives a multiplicity of henads and of powers and mingles them into one essence," (PT III 9. 40.6-8). Readers of the Platonic Theology who have seen in the procession of Being a process of multiplication, therefore, have gotten it precisely backwards, for this procession actually involves the many Gods coming together into a common, ultimately intellectual space.

It is a misinterpretation of Proclus, moreover, to see in the existence of a multiplicity of individuals a decline from unity. Proclus specifically rejects that "the procession of the whole of things" should come about "through a diminution [huphesin], rather than through a superabundance of goodness," (PT II 7. 50. 2122). "Diminution" here is that hupobasis defined as the production by monads of things "as if from the entirety of their natures but diminished for particular instances, their specific character being preserved but becoming more partial in them," like, for example, intellects from Intellect (IP 746). This process is not to be used to account for procession as a whole. ${ }^{7}$ The One does not produce the totality by "employing power," (50.25-26) that is, through the activation of potentialities, but rather the One "produces all things by being exempt from all things, and by being unparticipated, similarly generating the first and last of beings," (50.9-11). It is not just that the One produces all things while remaining transcendent. This would be to render Proclus's statement banal and void of explanatory power. Rather, it is that the One's transcendence - that is, individuality's transcendence - is the very thing that brings production about through the very irreducibility of the existential individual to objective definition.

This tension between individual huparxis and universalizable potencies produces Being, but it also goes along with a decline in the intensity of existence for beings, for ontic individuals "do not have a simple essence, nor uniform [monoeideis] powers, but are composed out of opposites," (PT I 18. 85.18-20) and "subsist from adversaries," (85.24). Our existential individuality, which is to some degree in common with the Gods, is obscured, in effect, by our particularity, which consists in the polemos (86.8) by which "things coming to be in a foreign place [en allotria chôra], by introducing the universal, dominate the physical substrate by means of the form," (86.5-6). In this we are different from the Gods, of whom "each is simply self-sufficient goodness ... not according to participation or illumination or likeness possessing self-sufficiency [to autarkes] and total perfection but just by being what s/he is," (PT I 19. 91.13-16) for "there is nothing in them which is not one [hen] and existence [huparxis]," (92.16-17). "The peculiarity of existence [idiotês tês huparxeôs]," Proclus explains, "diversifies [exallattei] the procession of each goodness," (91.10-11) that is, of each God. The procession of Being is determined by the "peculiarities" of just the

\footnotetext{
${ }^{7}$ Contra Trouillard, La Mystagogie de Proclos (112-113), who sees the "modèle" for "le passage de l'Ineffable à la totalité," in "la dérivation que Proclos appelle kath'hupobasin (par marche dégressive), qui est la génération des parties par le tout."
} 
Gods that happen to be, but these peculiarities are also reserved in some sense from that procession and hence conserved in it. In reserving their supra-essential individuality, the Gods allow to the intellectual domain, the domain of what we would call ontology, the realm of the Mixed qua Mixed, that degree of selfsufficiency that it possesses. ${ }^{8}$

Because the second and third intelligible triads actually express the nature of Gods, not simply qua Gods, but also as members of the intelligible-and-intellectual class and the intellectual class respectively, a discussion of those triads would be appropriate to an account of the activities of the Gods in those orders. Just to recognize this is already to take a major step toward the correct understanding of the Platonic Theology. What belongs properly to the discussion of the intelligible Gods is to explain what is involved in a God "proceeding to the intelligible summit." What does a God do in proceeding to the illumination of Being, regardless of the specific region of Being that God illuminates? For in general one must take the higher planes of Being as the sites of a more universal activity. Limit, Proclus explains, is "divine existence", the Unlimited, "generative power", and the Mixed is "the essence proceeding from these," (PT III 27. 93.1518). Elsewhere, he says that the mixture "is a union [henôsis] unto [eis] the hypostasis of Being," (PT III. 9. 37.4-5). What happens to a God, who is supraessential, in becoming or acquiring essence? If the essence proceeds from the huparxis, or existential individuality of the God, and from the powers of that God, not power in the sense of force, but in the sense of properties of that individuality, and this is indeed what the first two moments of the first intelligible triad signify, then the "essence" of the God is the reconciliation of the opposition between this existential character and the properties which are potential universality, with which the God is "pregnant", as Proclus frequently terms it. ${ }^{9}$ The differentiation of powers from the integrity of the divine person is the thinking, as it were, by the God of his/her attributes, which creates the space of reflection in which beings dwell. It is in this sense that the opposition of existence and powers is intellectual.

Proclus explains the difference between thinking in humans and in the Gods in the following manner: for us, knowledge is a coming-to-plenitude, while in the Gods, intellect is generated from their plenitude, "for the progression in them is not from an imperfect state to a perfect one, but from the existence perfect in itself [ek tês autotelous huparxeôs] comes the power that engenders lesser enti-

\footnotetext{
8 "One calls the intellectual cosmos self-sufficient insofar as it has established the universal good [to holon agathon] in eternity [en aiôni], comprehends at once [homou] its whole blessedness, and lacks nothing, because all life and intelligence are present with it, and nothing is deficient, nor does it desire anything as absent. This indeed is self-sufficient in its own class [en têi heautou taxei], yet it falls short of the self-sufficiency of the Gods," (PT I 19. 91.1-7).

${ }^{9}$ E.g., at PT I 24. 108.22-23, where the wisdom [sophos] of the Gods, which corresponds to the second moment of the first intelligible triad, is said to be "pregnant with intelligible light and the very first forms [eidê]."
} 
ties [hê gonimos tôn hupodeesterôn dunamis]," (PT I 23. 105.14-19). Already in Plato's Phaedrus (247a5-e7), we see the Gods assembled in a symposium seemingly the model for the human symposium in the dialogue of the same name: assembled for a banquet, the Gods feast themselves upon the intelligible attributes primarily instantiated in none other than themselves. This divine symposium, as it were, is constitutive of the noetico-noeric organization, but has its ground in what each of the Gods does for him/herself, namely cognizing his/her own properties, which alone makes it possible that we might do the same, for according to Proclus "if all intellect is intelligible to itself, it is through the intelligible Gods that it possesses this characteristic," (PT III 28. 100.15-16).

I spoke above of the procession of the Gods into Being as involving the production for each of an ontic "double". This doubling has its primary expression in the third moment of the first intelligible triad, in which Being "receives a multiplicity of henads and of powers and mingles them into one essence," (PT III 9. 40.6-8). Proclus's account of the third intelligible triad, however, which pertains strictly speaking to the disposition of an intellectual God, explicates the Gods' presence to Being which was expressed universally in the third moment of the first triad. In the third moment of the first triad, the moment of the Mixed, each God is, immediately, Being Itself, whose components, Limit and the Unlimited, are simply the existence and power(s) of each God. In the third intelligible triad, Proclus explains, "unitary multiplicity [to heniaion plêthos]," that is, the multiplicity of the Gods, "is conjoined to the multiplicity of beings," (PT III 26. 89.16-17). A multiplicity of henads and a multiplicity of beings are present in one ideal space, a space of mediation; hence where Proclus referred to the second intelligible triad as wholeness, the third intelligible triad is allness, totality ( $P T$ III 20. 71.8-10). The One and Being confronting one another, so to speak, "the One and Being generate a second henad conjoined with a part of Being," and Being "generates a more partial being suspended from a more partial henad," this being the division, diairesis, of the One and the distinguishing, diakrisis, of the One and Being (89.22-26).

The generation of a "second henad" together with a more partial being refers to the emergence of specific levels of Being from the activities of the Gods, activity (energeia) being the third moment of all triads taking their form from the first intelligible triad: each God is existence, power, and activity. Their activities, which we know of through myths conveyed to poets through divine inspiration, ${ }^{10}$

\footnotetext{
${ }^{10}$ In his Cratylus commentary Proclus characterizes the works of poets such as Homer as the product of souls "at one time operating enthusiastically about the Gods and at another time operating according to science," (71). At IC 87 he characterizes the "enthusiastic" component further as coming about though a variant form of anamnêsis or recollection, namely, "through the love of a divine nature, and the recollection of the huparxis of deity." This recollection of the Gods refers to the account in the Phaedrus of the soul's pre-natal experience as a "follower" of one God or another, the recollection of which influences the soul throughout its embodied life and plays an important role in
} 
allow us to classify the Gods according to the specific planes of Being constituted through their illumination. It is this symbolic action through which the Gods, in effect, bring forth and resolve the latent alterity in themselves. The Gods are primordially distinct by virtue of each possessing his/her unique idiotês. This individuality is not originally given diacritically, negatively, holistically, but instead with primitive positivity. Explicating this primitive identity, however, manifests alterity through the Gods' powers, as well as through the presence of all the other Gods in each one.

Of previous treatments of the nature of the first intelligible triad, the most perspicacious and insightful is clearly Gerd van Riel. ${ }^{11}$ Van Riel answers in the negative the question posed in the title, and also recognizes that Limit and the Unlimited "ne sont pas réellement distincts au niveau intelligible," (428) but does not go on to explain the significance of this, for he does not acknowledge authentic individuality in the henad, seeing in the idiotês of the God "une caracteristique typique" (424). I would argue that the primary idiotês is not a type but rather a unique individuating property. Van Riel recognizes that "unité (henôsis) et spécificité (idiotês) constituent les existentalia des hénades," (ibid.) but does not recognize that in the henads these are one and the same, for the "unity" of the henads is their individuality. The idiotês of the God is thus a primitive character, not "une place particulière dans la procession causale," (ibid.). To give idiotês a solely classificatory sense is to dismiss Proclus' commitment to the reality of unique divine persons. As Van Riel acknowledges, the exact number of the henads is only knowable to the Gods, although it can be determined a priori to be finite (422 n. 30). But since the number of ontic classes is known to us, the henads cannot therefore be individuated in relation to the classes of beings, as the "typical characters" or "regulative principles" for those classes (426). In fact, it is rather the case that singular hypostases participate in classes of Gods; thus, for example, ET prop. 163 defines the intellectual class of Gods as follows: "Every manifold of henads participated by the unparticipated Intellect is intellectual." The number of henads is not fixed to the number of ontic classes because "the individuality of each of them [the henads] is a much more perfect thing than the difference of the Forms," (IP 1048). Hence Proclus, except for purposes of exemplification, speaks of classes of henads and leaves to the sacred discourses of theologians the accounts of individual Gods. Reducing the henads to logical counters both fails to do justice to Proclus' theology and also, more importantly, mystifies the constitution of Being, inasmuch as it is from out of polycentric henadic individuality than ontic unity - formal, universal, mediated - comes to be.

its intellectual development (note in this respect that "beauty" emanates from the third intelligible triad, i.e., from an intellectual God, one who places him/herself in proximity to souls).

11 "Les hénades de Proclus sont-elles composées de limite et d'illimité?," Revue des sciences philosophiques et théologiques 85 (2001), 417-432. 
In summary, I have argued that the intelligible Gods are to be understood, not as a discrete set of Gods, but, according to the broad sense of Being, as all the Gods in their primary disposition as a polycentric manifold, and that accordingly, the divine activity that generates the procession of Being as recounted in the Platonic Theology is not a process in which a multiplicity of Gods come to be from one, but rather a process in which a common intellectual space comes about among the Gods as a resolution of the opposition between unique individuality and universalizable potencies - that is, between existence and power - in each God. That this opposition is resolved in symbolic action in turn grounds Proclus' project of interpreting myth as the bringing forth of the moments of Being by the Gods. In my interpretation, Being is brought forth, in effect, through the emergence of self- and other-relatedness among the Gods. In the reading I have suggested for the Platonic Theology, Being comes to be through the self-analysis of ultimate individuals which results in the constitution of a monocentric order from out of polycentric henadic autarchy through the generation of classes or kinds in the expression of power(s). The categories from which the dialectic of the Platonic Theology begins, therefore, may be in one sense the most general and hence most empty; but only by willfully ignoring that they also stand for concrete existential unities, could this unfolding be taken as in any respect "external". 